\title{
'n Huldiging: Tjaart van der Walt
}

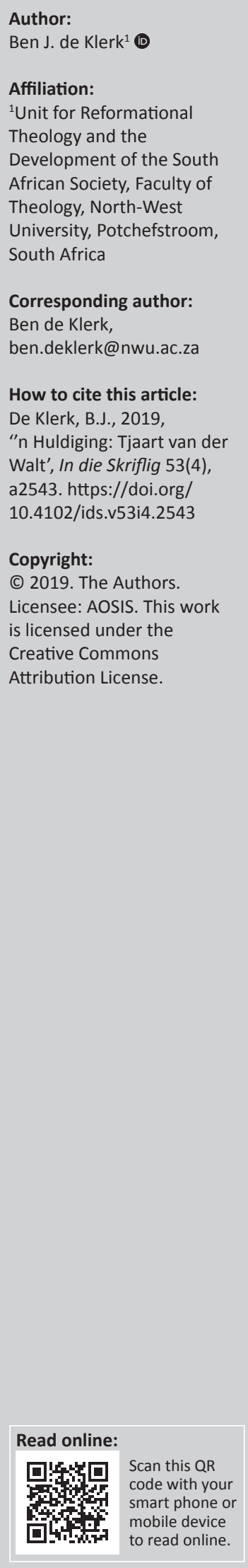

Tjaart van der Walt is op 15 Februarie 1934 in Pietersburg gebore. Hy slaag sy matriekeksamen met onderskeidings in al sewe vakke - wat in daardie jare uitsonderlik was. Hy behaal al sy grade met onderskeiding - van die Baccalaureus Artium (BA) (ook Honneurs in Klassieke Tale) tot met die voltooiing van die doktorsgraad in Teologie. Na die voltooiing van sy studie op Potchefstroom is hy na Nederland om sy doktorsgraadstudie onder die wêreldbekende Nuwe-Testamentikus, prof. Herman Ridderbos, aan die Johannes Calvyn Akademie in Kampen af te rond. Sy proefskrif met die titel, 'Die koninkryk van God - naby!', wat deur J.H. Kok in boekvorm uitgegee is (Van der Walt 1962), is ' $n$ insiggewende, rigtinggewende en akademies-uitstekende werk, bekroon met summa cum laude. Van der Walt sterf op 23 Februarie 2019 in die ouderdom van 85 jaar.

In 1969 word hy as professor in Nuwe-Testamentiese vakke aan die Teologiese Skool en aan die Fakulteit Teologie van die Potchefstroomse Universiteit vir Christelike Hoër Onderwys (PU vir $\mathrm{CHO}$ ) beroep en bevestig. Hy begin dadelik met skryfwerk aan diktate om die vakgebied uit te brei. As Bybelvertaler en lid van die eindredaksie werk hy mee aan die verskyning van die 1983-Afrikaanse Bybelvertaling. Tjaart het sy betrokkenheid by die Bybelvertaling as ' $n$ hoogtepunt in sy loopbaan uitgesonder en hy het tot die week voor sy dood steeds aantekeninge in sy Bybel gemaak, want hy was nie net student van die Woord nie, maar ook 'n gehoorsame luisteraar na God se stem.

Van der Walt voer aan dat daar nie net van een lyn deur die Bybel gepraat moet word nie, maar dat die Bybel soos 'n diamant is wat skitter van watter kant jy ook al daarna kyk (Van der Walt 2007:37). Nogtans is dit besonder waardevol om minstens een lyn wat dwarsdeur die Bybel loop, te probeer natrek. So kan die eenheid in die verskeidenheid skerp na vore kom. Hy vra verder wat die kern, die hart van die Bybel is. Vroeër is baie aandag aan die begrip verbond gegee en dit is steeds baie belangrik. Sedert die middel van die twintigste eeu het die fokus toenemend na die koninkryk van God verskuif. Sy proefskrif wat vroeg in daardie periode die lig gesien het, was net soos Ridderbos se 'De komst van het Koninkrijk' (1950) baanbrekerswerk om die betekenis en sentrale lyn van die Godskoninkryk uit te bou.

Die vertrekpunt in sy werk as Nuwe-Testamentikus is die eenheid tussen die Ou en Nuwe Testament, wat hy met die begrip koninkryk van God illustreer. Die basiese betekenis van die koninkryk van God is dat God Koning is en dat Hy regeer, maar daar is ook 'n teë-koning, 'n rebelle-koning: die duiwel (Van der Walt 2007:44). Daarom is daar 'n dodelike stryd tussen die Koning van die lig en die heerser oor die duisternis. Daar is twee basiese fases in hierdie oorlog: In die Ou Testament is die tragiese geskiedenis van God se bondgenote wat Hom telkens in die steek laat en dit mag voorkom asof die Satan die oorhand kry, want die volk word tot die koninkryk van Juda verklein. Hulle was net 'n handjievol Jode wat die oorblyfsel uit die ballingskap is, en hulle misluk weer. Daar was in hierdie stryd net een uitweg: die Christus, die Seun van die mens, 'n mens van vlees en bloed moes kom. Hy behaal met sy dood en opstanding die beslissende oorwinning en so breek die nuwe tyd aan - die Nuwe-Testamentiese tyd - waaruit blyk dat God se koninkryk onstuitbaar deurbreek (Van der Walt 2007:46). God se koninkryk het gekom, kom steeds en sal uiteindelik in volmaaktheid kom!

Daar is veral drie betekenisse van die koninkryk van God. Die eerste en verreweg die belangrikste is dat God Koning is en dat Hy regeer. Die koninkryk van God is 'n dinamiese begrip wat vol aksie is. God is besig om te regeer en hierdie persoonlike karakter van die koninkryk stel gelowiges regstreeks voor die Koning self. Die koninkryk beteken ook die magsfeer van sy heerskappy, asook van die burgers van wie Hy die Koning is. Oral waar die wil van God gehoorsaam word, daar kom sy koninkryk. Die koninkryk dui ook aan wat gebeur waar die Koning regeer, die vrug van sy koningskap en die seëninge vir sy onderdane: vrede, vreugde, geregtigheid, heiligheid en heerlikheid (Van der Walt 1962:39).

In sy proefskrif kom die vraag oor Jesus se aanvangsprediking (God se koninkryk het naby gekom) na vore: Wanneer kom die nabye koninkryk nou eintlik - enige oomblik, of sou dit nog jare, selfs eeue duur? (Van der Walt 1962:2). Van der Walt (1962:14) antwoord soos volg: 
Jesus verwag sekerlik die deurbraak van die eschaton in die nabye toekoms. 'n Vergissing is dit nie, want met kruis en opstanding, hemelvaart en Pinkster kom die Koninkryk inderdaad met krag, sonder dat hierdie vervulling enigsins die volledige realisering van die Wederkoms en Laaste Oordeel uitsluit.

God se koninkryk het met Jesus se koms en sy voltooide werk op aarde naby (mense) gekom, maar mense het ook naby die koninkryk gekom. Daarom moet die koninkryk ook deur mense gesoek word, verwag word, daarvoor gebid word en ontvang word. Die koms van God se koninkryk is nie 'n geheimsinnige en onsigbare saak nie, maar manifesteer en word vergestalt in die uitbanning van demone deur Jesus. Dit is ' $n$ duidelike bewys dat die koninkryk van God gekom het. Jesus se daad wys ook na die toekoms wanneer die koninkryk meer sal wees as net naby (Van der Walt 1962:41). Slegs diegene wat 'n geloofsoog en -oor ontvang het, sien en hoor God se koninkryk wat nie net in aantog is nie, maar reeds begin deurbreek het en dus reeds gekom het.

Daar is veral ook die finale koms wanneer Jesus eers weer sal drink van die vrug van die wynstok wanneer God se koninkryk gekom het - hier onmiskenbaar die Voleinding. Die koninkryk kom egter ook in die tyd tussen die eerste koms en die Voleinding. Van der Walt (1962) stel dit so:

Die koms van die Koninkryk as teenwoordige en as toekomstige werklikheid is geen disparante groothede nie, maar daar is 'n wesentlike kontinuïteit tussen beide, en wel in die sin dat hulle verskillende fasette is van een en dieselfde saak of proses. Maar dan nie die enigste fasette nie! Op die begin volg nie direk die einde nie: 'n noodsaaklike tussentyd waarin die saad groei en die suurdeeg sy gistende werk verrig, skei en verbind begin en einde. (pp. 50 - 51; vgl. Mark 13)

Hierdie tussentyd is egter geen blote intermezzo of interim, 'n lugleegte of omweg nie, maar óók koms van God se koninkryk.

Aan die einde van die proefskrif dui Van der Walt die sentrale plek van die Koning Christus en die roeping van die koninkryksburgers in die koms van die koninkryk aan. Hy oordeel dat daar alleen in Christus veiligheid in die onveiligheid van die toekoms en sekerheid in die onsekerheid van die koninkryksaantog is. Niemand kan dus 'n toeskouer bly nie. Die Koning van die koninkryk het ons oë geopen nie om ons nuuskierigheid te bevredig nie, maar juis om die toeskouershouding radikaal te deurbreek. Die toeskouer word so tot die besef gebring dat hy en sy opgeneem is in diens van die Koning in die voltrekking van sy groot heilswerk - die koms van sy koninkryk. Hulle moet insien dat die koninkryk reeds aan die werk is en daarom moet hulle hul hoop vas op die toekoms vestig, maar die wanneer en die hoe volledig in die hande van die Vader laat. Die toeskouer moet verder weet dat hulle deur hierdie nabyheid van die koninkryk reeds nou al voor die wesenlike beslissing gestel word - 'n beslissing vir of teen die Koning van die koninkryk. Van der Walt dui aan dat alles daarom op radikale navolging van hierdie Jesus aankom, op die weg wat Hy gebaan het tot die koms van die Koninkryk in al sy volheid, want hierdie weg is self die koms van die koninkryk. Die toekoms is seker en die einde is naby (Van der Walt 1962:318).
Tjaart van der Walt kry in 1974 die geleentheid om in 10 preke oor die profetiese rede die werk in sy proefskrif konkreet toe te pas. Hy skryf onder andere die volgende: Waarom laat God nog nie die einde, ons einde, die wêreld se einde aanbreek nie? Omdat ons nog evangeliewerk het, want die evangelie moet verkondig, uitgedra en uitgeleef word aan alle mense (Van der Walt 1974:61). 'n Christen kan nooit ' $n$ pessimis wees nie, want Christus sê die einde van die óú wêreld, die stukkende wêreld waarin ons leef, is die begin van die nuwe. Die aarde se siekbed is nie 'n sterfbed nie, maar 'n kraambed. Voor ons is nie 'n wêreldnag nie, maar die breek van 'n nuwe dag (Van der Walt 1974:45). Elke traan is 'n profeet van die dag wanneer God self die trane van ons oë sal afvee. Elke hartseer is 'n boodskapper van die nuwe hemel en die nuwe aarde waar géén dood, géén droefheid, géén geween en moeite meer sal wees nie, maar ons altyd by God sal wees, en Hy by ons. Dis die môre wat God ons gee. En sy môre begin al vandag! (Van der Walt 1974:46).

\section{Erkenning Mededingende belange}

Die outeur verklaar dat hy geen finansiële of persoonlike verbintenis het met enige party wat hom nadelig kon beïnvloed in die skryf van hierdie artikel nie.

\section{Outersbydrae}

B.J.d.K. is die enigeste outeur betrokke by die skryf van die artikel.

\section{Etiese oorwegings}

Hierdie artikel volg alle etiese standaarde vir navorsing.

\section{Befondsing}

Hierdie navorsing het geen spesifieke toekenning ontvang van enige befondsingsagentskap in die openbare, kommersiële of nie-winsgewende sektore.

\section{Data beskikbaarheidsverklaring}

Die deel van data is nie van toepassing op hierdie artikel nie.

\section{Vrywaring}

Die sienings en menings wat in hierdie artikel uitgedruk word, is dié van die outeur en weerspieël nie noodwendig die amptelike beleid of posisie van enige geaffilieerde agentskap van die outeur nie.

\section{Literatuurverwysings}

Van der Walt, T., 1962, Die Koninkryk van God - Naby! Eksegetiese verkennings van die toekomsperspektief van Jesus Christus volgens die getuienis van die Sinoptiese evangelies, J.H. Kok, Kampen.

Van der Walt, T., 1974, God se môre begin vandag - rol op jou moue! Pro Rege, Potchefstroom.

Van der Walt, T., 2007, Die Messias het gekom!' $n$ Gids in die Evangelies vir toegewyde Bybel-studente, Potchefstroomse Teologiese Publikasies, Potchefstroom. 